\title{
DETERMINANTS OF SAVINGS MOBILIZATION AMONG AGRICULTURAL MICRO CREDIT FINANCE GROUP MEMBERS IN DELTA STATE, NIGERIA
}

\author{
Enimu Solomon*, Eyo O. Emmanuel, Edet G. Onome \\ Department of Agricultural Economics, University of Calabar, Nigeria \\ *E-mail: solomonenimu@gmail.com
}

\begin{abstract}
The study was carried out to examine the determinants of savings mobilization among Agricultural micro credit finance group members in Delta State, Nigeria. Forty eight (48) micro credit groups and three hundred (300) micro credit group members were selected randomly from the sample frame and interviewed using structured questionnaires. Descriptive and inferential statistics were employed for the analysis of the data collected. The results of the multiple regression analysis revealed that a significant relationship at $1 \%$ level existed between amount of savings mobilized and age of group members, household size, educational level, group duration, distance to credit source, interest charged and member monthly income. It was also observed that $85 \%$ of the groups have existed for about 110 years with a mean group savings of $\mathrm{N} 355,500$ and an average group size of 13 persons. $92 \%$ of the micro credit groups adopted the non-random method of fund allocation with a mean distance traveled to source of credit at 15 kilometers and the mean interest charged on loans was 40 percent.
\end{abstract}

\section{KEY WORDS}

Determinants, savings, mobilization, micro credit, groups.

Agriculture in Nigeria, a developing economy has suffered serious setbacks due to under capitalization. Poor credit disbursement procedures, inadequacy of credit institutions to cater for the needs of the teaming population of farmers and poor loan repayment possibilities among farmers (Eyo and Enimu, 2015). Micro credit is about providing services to the poor who are traditionally not served by the conventional financial institutions (Upton, 1997). The pivotal place of capital in economic growth and development cannot be overemphasized and had been recognized since the pre-Keynsian era till date, because the classical ideology that monopolized economic thinking and policy formulation has stress capital to be so. It is a known fact that nations of the World place tremendous emphasis on capital accumulation by emphasizing the notion of savings that will increase the level of investment in relation to output (Igben and Enimu, 2016).

In agriculture for instance, if farmers are unable to create wealth, their ability to mobilize savings that will guarantee credit which will buffer loan repayment will be strongly hindered; and low capital accumulation can lead to financial exclusion (Deon, 1995). According to Thirlwall (1999), capital formation could be adjudged as the endogenous consequences of growth and also an exogenous cause of growth.

The role of savings is showed in capital accumulation through improved capital assets and the effects it has on the ability of an economy to make more incomes (Angyie, 2005). Savings which is regarded as a catalyst for the accumulation of capital and also a deciding factor of the cost of credit as can been seen from the law of scarcity which says that when the former is low and scare, it becomes costlier to obtain the latter (Rose, 1986). According to the classical view, savings is a major yardstick and determinant of economic growth and development. According to the World Bank (1999), developing countries that attain higher growth rate are the ones that have high savings capacities. Capital mobilized from domestic sources is very fundamental for a country's development not only because it has a low cost but also because it is durable and permanent.

Most domestic savings emanates from the rural areas usually in under-developed countries with high rural population due to the fact that there are greater savings ability and 
growth potentials (Thillairajah, 1994). Also in these areas, characterized by unstable economic conditions, there is usually a high propensity to save (Yaron, Benjamin and Piprek, 1997). They further stressed that savings enable a large portion of clients to have access to credit as well as enable rural people and farmers in particular to establish or develop income generating activities and improve on their income level. The merit accruing to savings by the rural people is demonstrated through the various means and ways they used in saving and also by keeping little amount at home for immediate use (Enimu, Igiri and Uduma, 2015). In furtherance of this, when rural peoples' desire and need to save meet a safe, easily reachable avenue to operate, their ability to save and willingness to save and the amounts they will be able to save are considerably substantial.

Consequently, the study aims at establishing the determinants of savings mobilization among micro credit finance group members in Delta State, Nigeria with a view to improve the design and stimulate mobilization of rural savings for economic growth and development. The broad objective of this study is to examine the determinants of savings mobilization among micro credit finance group members in Delta State, Nigeria. The specific objectives include to describe the characteristics of agricultural micro credit finance groups in the study area; examine the operating characteristics of agricultural micro credit finance groups; assess savings mobilizations strategies of agricultural micro credit finance groups and analyze the determinants of savings mobilization among micro credit finance groups.

\section{METHODS OF RESEARCH}

Study Area. Delta State is one of the six states that make up the South-South geopolitical zones of Nigeria. The state was formed in August 27, 1991 out of the former Bendel State. The state consists of twenty-five (25) Local Government Areas. Delta State is located between longitude $5^{\circ} 00^{1}$ and $6^{0} 45^{1} \mathrm{E}$ and latitude $5^{0} 00^{1}$ and $6^{0} 30^{1} \mathrm{~N}$. It is bounded by Edo State on the north, on the northwest by Ondo State. Anambra State on the east and in the South east by Bayelsa State. On the southern flank is the Bight of Benin which covers approximately $160 \mathrm{~km}^{2}$ of the state's coastline (FOS, 1996). The state is marked by two seasons as a tropical climate. The dry and raining seasons with a dry spell in August commonly referred to as "August Break". The average annual rainfall is about $2667 \mathrm{~mm}$ in the coastal areas and $1905 \mathrm{~mm}$ in the northern areas. Rainfall is heaviest in July. Delta State has a high temperature ranging between $29^{\circ} \mathrm{C}$ and $44^{\circ} \mathrm{C}$ with an average of $30^{\circ} \mathrm{C}$.

The vegetation consists of the mangrove swamp forest along the coastal areas and the thick rain forest in the middle and the Savannah in the north. The 2006 population census puts the population of Delta State at 4,098,391 made up of 2,074,306 males and 2,024,085 females, with a land area of $17,011 \mathrm{~km}^{2}$ (NPC, 2006). Delta State is purposely selected for this study because the state has many micro credit groups in the formal and informal linkage self help programmes sponsored by the Federal/State Government and Non-Governmental Organizations (NGOs) and Corporations.

Sources of Data. Primary and Secondary data were used in the study. Primary data were obtained through a well-structured questionnaire complimented with oral interview by well trained enumerators on the operating and savings mechanics of the micro credit finance groups while secondary data were obtained from their books of accounts and other published and unpublished materials.

Sampling Technique and Data Analysis. A stratified random sampling technique was applied in sample selection. A total of 48 micro credit finance groups and 300 micro credit group members were selected randomly for the study. Data obtained were analyzed using descriptive statistics such as table, frequency distribution, percentage and mean while the multiple linear regression analysis was the inferential statistical tool used.

The Empirical Model. In the regression model used, it was postulated that amount of savings mobilized by micro credit group members (SM) is a function of Age of the respondent $(A)$ in years, household size $(H)$ in number, educational level $(E)$ in years, group duration $(G)$ in years, distance to credit source (D) in kilometers, Interest charged (I) in percentage, sex of respondent $(S)$, monthly income $(M)$ in naira, Religion $(R)$ and ethnicity $(C)$. 
Consequently, the mathematical model is expressed as:

$$
S M=f(A, H, E, G, D, I, S, M, R, C)
$$

The a priori expectation is that:

$$
S M=b_{0}+b_{1} A-b_{2} H+b_{3} E+b_{4} G-b_{5} D+b_{6} l+b_{7} S+b_{8} M-b_{9} R+b_{10} C
$$

Where: $b_{0}$ is a constant, $b_{1}-b_{10}$ are the parameters.

\section{RESULTS AND DISCUSSION}

Characteristics of Agricultural Micro Credit Groups. The various agricultural micro credit groups have different characteristics that can affect their operational and savings mobilization performance.

\begin{tabular}{|c|c|c|}
\hline VARIABLES & FREQUENCY (n-48) & PERCENTAGE \\
\hline \multicolumn{3}{|c|}{ Group existence (Age) Years: } \\
\hline $1-5$ & 26 & 54.17 \\
\hline $6-10$ & 15 & 31.25 \\
\hline $11-15$ & 4 & 8.33 \\
\hline Above 16 & 3 & 6.25 \\
\hline Mean $=8$ & Minimum $=2$ & Maximum = 18 \\
\hline \multicolumn{3}{|l|}{ Group Savings Made } \\
\hline Less than $\mathrm{N} 200,000$ & 15 & 31.25 \\
\hline $200,001-300,000$ & 23 & 47.92 \\
\hline $300,001-400,000$ & 7 & 14.58 \\
\hline Above 400,001 & 3 & 6.25 \\
\hline Mean $=355,500$ & Minimum $=\mathbf{8 0 , 0 0 0}$ & Maximum $=520,000$ \\
\hline \multicolumn{3}{|l|}{ Group Size } \\
\hline $5-10$ & 12 & 25.00 \\
\hline 1115 & 25 & 52.08 \\
\hline $16-20$ & 7 & 14.48 \\
\hline Above 21 & 4 & 8.33 \\
\hline Mean $=13$ & Minimum $=6$ & Maximum $=24$ \\
\hline \multicolumn{3}{|l|}{ Method of fund Allocation } \\
\hline Random & 4 & 8.33 \\
\hline Non-random & 44 & 91.67 \\
\hline \multicolumn{3}{|l|}{ Meeting Attendance } \\
\hline Once a week & 23 & 47.92 \\
\hline Twice a month & 18 & 37.50 \\
\hline Once a month & 7 & 14.58 \\
\hline \multicolumn{3}{|c|}{ Distance to credit Source $(\mathbf{k m})$} \\
\hline $1-10$ & 27 & 56.25 \\
\hline $11-20$ & 13 & 27.08 \\
\hline $21-30$ & 5 & 10.42 \\
\hline Above 31 & 3 & 6.25 \\
\hline Mean $=15$ & Minimum $=1$ & Maximum $=32$ \\
\hline \multicolumn{3}{|l|}{ Supervision (No. of Visit) } \\
\hline $1-5$ & 16 & 33.33 \\
\hline $6-10$ & 23 & 47.92 \\
\hline $11-15$ & 6 & 12.50 \\
\hline Above 16 & 3 & 6.25 \\
\hline \multirow{2}{*}{\multicolumn{3}{|c|}{$\begin{array}{l}\text { Mean = } 15 \\
\text { Interest on Loan (\%) }\end{array}$}} \\
\hline & & \\
\hline $\begin{array}{l}\text { Less than } 10 \\
10-30\end{array}$ & $\begin{array}{l}6 \\
18\end{array}$ & $\begin{array}{l}12.50 \\
37.50\end{array}$ \\
\hline Above 30 & 24 & 50.00 \\
\hline Mean $=40$ & Minimum = 8 & Maximum $=70$ \\
\hline
\end{tabular}

Table 1 - Characteristics of Micro Credit Groups

Source: Field Survey, 2016. 
Table 1 presented the characteristics of the groups. The table revealed that $57 \%$ of the groups have existed for about 6 - 10 years, while $31 \%$ of the groups have existed for more than 10 years. The mean duration of existence was 8 years, while the minimum duration was 2 years and the maximum was 18 years. The table also shows that $31 \%$ of the groups had savings less of than $\$ 200,000$ while $48 \%$ had saving ranging between $\$ 200,001$ - $\$ 300,000$. Only $21 \%$ of the groups had savings above $\$ 300,001$. The means membership strength of the groups was 13 persons with the minimum size of 6 persons and a maximum of 24 persons. While $52 \%$ of the groups have membership size of $11-15$ persons, $25 \%$ had a group size of $5-10$ persons while $23 \%$ of the groups had group size of above 15 persons. $92 \%$ of the groups observed the non-random method of fund allocation while only $8 \%$ of the groups practiced the random method of fund allocation. It therefore implies that majority of the groups uses the non-random method of fund allocation avoiding the serial turn -by-turn fund allocation that may bring about misunderstanding and misinterpretation of information for such groups that do not believe in lotteries which affect performance adversely. The table also indicated that $48 \%$ of the groups attends meeting once a week, $37 \%$ attend meeting twice a month while $15 \%$ of the micro credit groups attends meeting once a month. $56 \%$ of the group travel about $1-10 \mathrm{~km}$ to their credit source while $27 \%$ of the groups travel about 11 - $20 \mathrm{~km}$. $17 \%$ of the groups travel distances above $20 \mathrm{~km}$ to their credit source. On the number of visit paid to the groups by a credit officer, $48 \%$ of the micro credit groups had visitation of about 6 - 10 times while $33 \%$ had $1-5$ times. $19 \%$ of the groups had visitation above 11 times. The interest on loan was considered and $50 \%$ of the groups agreed that their interest rate was above $30 \%$, while $38 \%$ had interest rate of $10-30$ percent and $13 \%$ had interest that are less than 10 percent. The rate of interest appears to be higher than that of the commercial banks, but it is lower than the rate charged by money lenders.

Operating Characteristics of Micro Credit Groups. According to table 2, the most popular eligibility criteria for mobilization of savings are been a registered member of the group at $100 \%$, meeting the condition of registration such as having a farm or a trade at $100 \%$. Sincerity and honesty are other criteria that must be assessed before admitting into a group at $88 \%$. The agricultural micro credit groups serve their members in four capacities, namely: mobilization of savings and granting of loans at $100 \%$, mounting education programmes that will enhance economic activities of members at $50 \%$, and attending member's social activities such as marriages/burial/dedication and child naming ceremonies at $94 \%$.

From the table, the most popular loan monitoring strategy is to ensure that loan beneficiaries repay interest on loan during meeting at $100 \%$, while about $98 \%$ of the groups encourage presentation of the principal and interest during meeting. The agricultural micro credit groups mobilize internal savings for the running of the activities of the groups. $100 \%$ of the micro credit groups stated that their major savings mobilizing activities were, through registration fees, weekly/monthly savings, and fines while $54 \%$ uses weekly/monthly dues. $90 \%$ of the micro credit groups allow withdrawal of membership with replacement of a capable, honest person while $25 \%$ do not allow replacement of member during withdrawal of membership from the group. $46 \%$ of the micro credit groups do not allow withdrawal of membership from the groups.

Table 2 also revealed that $100 \%$ of the micro credit groups enticed their members to mobilize more savings through access to more loans, while $85 \%$ of the groups promise to elevate members to key position in the group if they performed creditably in savings mobilization throughout the year. $67 \%$ of micro credit groups base their incentive to better savings mobilization on awards from the micro credit institutions which is usually done at the end of very year. Apart from monitoring and incentives strategies, the groups employ nonfinancial sanctions. Table 2 showed that $100 \%$ of the micro credit groups use suspension from group and report to village/spiritual head as their major sanction for defaulters while $54 \%$ uses denial of next loan. Confistication and selling of properties, demotion from key position held and use of law enforcement agencies had $23 \%, 17 \%$ and $10 \%$ respectively. 
Table 2: Operating Characteristics of Micro Credit Groups

\begin{tabular}{|c|c|c|c|}
\hline & Operating Characteristics & Frequency & Percentage \\
\hline \multirow[t]{5}{*}{$\bar{a}$. } & Eligibility Criteria & & \\
\hline & Must register with the group & 48 & 100 \\
\hline & Must have savings with the group & 48 & 100 \\
\hline & Must be honest and sincere to the group & 42 & 88 \\
\hline & Must meet registration conditions & 48 & 100 \\
\hline \multirow[t]{5}{*}{ b. } & Group Functions/Activities to Members & & \\
\hline & Give loans to members & 48 & 100 \\
\hline & Settlement of dispute & 48 & 100 \\
\hline & Group educational programmes & 24 & 50 \\
\hline & Attending members social activities & 45 & 94 \\
\hline \multirow[t]{3}{*}{ c. } & Monitoring Strategies & & \\
\hline & Payment of Loan Interest during meetings & 48 & 100 \\
\hline & Payment of Principal and interest during meetings & 46 & 96 \\
\hline \multirow[t]{5}{*}{ d. } & Group Savings Drive & & \\
\hline & Registration fees & 48 & 100 \\
\hline & Weekly/monthly dues & 26 & 54 \\
\hline & Weekly/monthly savings & 48 & 100 \\
\hline & Fines & 48 & 100 \\
\hline \multirow[t]{4}{*}{ e. } & Withdrawal from Group & & \\
\hline & Withdrawal with Replacement & 43 & 90 \\
\hline & Withdrawal without Replacement & 12 & 25 \\
\hline & No withdrawal of Members & 22 & 46 \\
\hline \multirow[t]{4}{*}{ f. } & Incentives & & \\
\hline & Access to more Loans & 48 & 100 \\
\hline & Elevation to key position in group & 41 & 85 \\
\hline & Award from MFIs & 32 & 67 \\
\hline \multirow[t]{8}{*}{ g. } & Non-Financial Sanctions & & \\
\hline & Suspension from Group & 48 & 100 \\
\hline & Report to Village/Spiritual Heads & 48 & 100 \\
\hline & Denial of next Loan & 26 & 54 \\
\hline & Confistication and selling of Property & 11 & 23 \\
\hline & Demotion from key position held & 8 & 17 \\
\hline & Arrest by Law enforcement agencies & 5 & 10 \\
\hline & Maximum Responding Unit & 48* & \\
\hline
\end{tabular}

Source: Field Survey, 2016.

Multiple Responses were recorded.

Determinants of Savings Mobilization among Micro Credit Finance Group Members. Multiple regression analysis was applied to examine the socio-economic determinants of amount of savings mobilized among micro credit group members. Seven of the ten determinants included in the model affected the volume of savings mobilized significantly. These parameters include age of members, household size, educational level, group duration, distance to credit source, interest charged and monthly income.

Result shows that the $\mathrm{R}^{2}$ value of 0.956 means that about $96 \%$ of the differences in the volume of savings mobilized was due to the determinants captured in the model. Using a two-tail test at $1 \%$ level of significance, the F-computed is 297.95 and F-table is 2.58 , since the calculated $F$ is greater than the corresponding table value, we rejected the null hypothesis $(\mathrm{Ho}$, at $P>0.01$, b's $=0)$ which states that there is no significant relationship between the selected determinants and the amount of savings mobilized by the group members; and accept the alternative hypothesis.

The result of the regression analysis shows that the coefficient of member's age was significant at one percent and positively related to savings mobilized. This implies that, the higher the age of the group member, the higher the amount of savings mobilized. The result conforms to Olomola (2000) and Eyo, Otu and Sampson (2008). Household size was indirectly related to amount saved and was significant at one percent. The implication is that, the more people there are in a house, the less the house head is likely to save, indicating that if there are many people living under one roof, money which could have been saved will be used to meet other house hold needs like feeding, clothing and health bills. 
The coefficient of educational level was significant at one percent and positively related to amount of savings mobilized. This indicates that the higher the educational levels of group members, the higher the amount of savings he/she will be able to mobilized. Igben and Enimu, (2016) had opined that quality education is needed in group formation, management and savings mobilization strategies. In confirmation of a priori expectation, duration of group existence which implies the years of experience had a positive relation with amount of savings mobilized and was significant at one percent level. This implies that the higher the duration of group existence, the higher the amount of savings mobilized by the group. This work was in conformity with Eyo (2008) who opined that duration of group existence is a major factor towards group loan administration.

Distance to credit source was significant at one percent and negatively related to amount of savings mobilized. This shows that the longer the distance of the group members to the credit source the lower the amount of savings mobilized. This was in consonance with work done by Enimu,Igiri and Achike (2016) and Okpukpara (2005). The coefficient of interest charged was positively related to savings mobilized and was significant at five percent. It implies that the higher the interest rate on savings the higher the amount of savings made. Household monthly income was significant at one percent and positively related to savings mobilized. The implication is that, the higher the disposable income of the individual, the more willing the individual to save. This result agrees with the observations of Okoroeun (1992), Awosike and Nwoko (1983), who noted that the growth of income and distribution of income are the main determinants of savings. They also found out that because of low level of farm income there is severe limitation on farmer's savings capacity.

\section{CONCLUSION}

The study revealed that agricultural micro credit finance group members have high potential to save. The result of the study indicated by the multiple regression analysis showed that age of group members, household size, educational level, group duration, distance to credit source, interest rate charged and household monthly income which are the significant determinants captured have direct relationship with the dependent variable and hence each of them is an important component in determining the amount of savings mobilization among agricultural micro credit group members in the study area. Based on the foregoing therefore, it was recommended that interest rate on savings should be increased to help encourage better mobilization and that micro credit institutions should discourage long distance travelling by encouraging the use of agent and catchment banking system with the deployment of latest technological innovations and gadgets.

\section{REFERENCES}

1. Angyie, E.P. (2005). The Role of Bank Spread in the Efficient Mobilization of Domestic Savings in the Extreme Western Region of Cameroon. Savings and Development. 3 (6): $221-242$.

2. Awosike, K. and S.G. Nwoko (1983), Perspective in Rural banking: Rural Banking in Nigeria, UK Longman Publishers Inc.

3. Delta State (2005) Main fact. http:/www.deltastate.gov.ng. Retrieved May, 2015.

4. Deon, F. (1995), Estimating the World at Work; The World Bank, World Development Report, 3:355 - 365.

5. Enimu, S.; J. Igiri and A.I. Achike (2016), Analysis of the Effects of Micro Finance Banks Loans on the Livelihood of Small-Holder Farmers in Delta State, Nigeria. Journal of economic Affairs (EA): 61 (3): 381 - 390.

6. Enimu, S.; J. Igiri and I.S. Uduma (2015) An Assessment of the Performance of Community Banks in Financing Resource Poor Farmers in Delta State. International Research Journal of Marketing and Economics, 2 (10): 64 - 75. 
7. Eyo, E.O.; J.O. Otu and M.G. Sampson (2008). Homogeneity in Group Membership Social Characteristics and Loan Recovery: Implications for Success of Formal - Informal Sector Linkage in Akwa-lbom State, Nigeria. The Social Sciences. 3 (1): 173 - 176.

8. Eyo, E.O. (2008). Determinants of Success of Micro finance Schemes Serving the Agricultural Sector in Akwa-Ibom State, Nigeria. The Social Science. 3(1): 173-176.

9. Eyo, O.E. and S. Enimu (2015), Financing Agriculture to Support Economic Development in Nigeria: The Need for Banks to Re-strategize. Proceeding of the $29^{\text {th }}$ Annual Conference of Farm Management Association of Nigeria, Dutse, 582 - 587.

10. Federal Office of Statistics (1996), Social - Economic Development of Nigeria, Lagos.

11. Igben, M.S. (2016). Generating Capital Accumulation for Farm Growth in Rivers State Nigeria: The Cooperative Experience. The proceedings of Nigerian Association of Agricultural Economists $17^{\text {th }}$ Annual National Conference, Owerri: 687 - 691.

12. National Population Commission (2006). 2006 Population Census of Federal Republic of Nigeria, Provisional Result, Abuja.

13. Okoroeun, U.U. (1992) Small Farmers and their Finance Problems. Bullion, 7(4), 28 - 33.

14. Olomola, S.A. (2000), Effects of Membership Homogeneity on the Design and Performance of Informal Finance Groups in Rural Nigeria. Final Research Report Submitted to AERC. Nairobi, Kenya.

15. Okpukpara, B.S. (2005). Determinants of Choice of Financial Institutions among the Rural Savers Implication for Sustainable Rural Financial Savings Mobilization for Agricultural Development in Nigeria. The proceedings of the $19^{\text {th }}$ Annual Conference of Farm Management Association of Nigeria (FAMAN).

16. Rose, P.S. (1986). Money and Capital Markets. Plano, Texas Business Publication Inc.

17. Thillairajah, S. (1994). Development of Rural Financial Markets in Sub-Saharan African. The World Bank Discussion Paper, No. 219.

18. Thirlwall, A.P. (1999), Growth and Development: With Special Reference to Developing Economics. (6 ${ }^{\text {th }}$ Ed.) Cheltenhan: Edward Elgar, $32-56$.

19. Upton, M. (1997), The Economics of Tropical Farming System: Promotion of Rural Credit. Rural Resources Economics Cambridge, Cambridge University, Press.

20. World Bank (1999), Proceedings of World Bank Summit on Micro Credit, Washington D.C USA, February.

21. Yaron, J., M.P. Benjamin and G.L. Piprek (1997). Rural Finance: Issues, Design and Best Practice. The World Bank, Washington, D.C. 